\title{
FACTORS AFFECTING INNOVATIONS IN SERVICE SECTOR ENTERPRISES: THE CASE OF LIEPAJA
}

\author{
Daina Vasiḷevska, Diāna Līduma \\ Liepaja University, Latvia \\ E-mail: daina.vasilevska@gmail.com, diana_liduma@inbox.Iv \\ Kitija Melberga \\ SIA Liepājas Olimpiskais centrs, Latvia \\ E-mail: melberga.kitija@gmail.com
}

\begin{abstract}
Within the framework of the research, it was clarified that there is a trend in the service companies in Liepaja to rely more on the technological innovations. That differs from the dominating trend in this sector to introduce the non-technological innovations. Considering the common trend in Latvia that the number of innovative service companies is decreasing, the factors preventing the introduction specifically in the service companies in Liepaja were identified in the research.

Aim of the research is to clarify the opinion of managers of service companies in Liepaja about the factors affecting introduction of innovation. Within the framework of the research, 31 highest-level managers of Liepaja City service sector and municipal companies were inquired. The results of the research showed that $90 \%$ of respondents have introduced at least one form of innovations since January 2014. It was established that the main forms of innovations by object in the service companies in Liepaja are product or process innovations. Only 35\% of the managers could clearly answer about their plans to introduce innovations in the future. That demonstrates the lack of strategy and innovations in the management and short-term planning in the companies. The results of the research allowed concluding that the main factor delaying innovations in the service companies was the shortage of financial resources. The lack of qualified staff was mentioned by the managers as an insuperable problem to introduce innovations.
\end{abstract}

Keywords: innovative business, service companies, forms and factors of innovations.

\section{Introduction}

Nowadays, the issues related with the development and growth of economics are related with the idea of innovation that can be implemented in any field of national economy. Not only in a private business but also in state sector. The research discusses the forms of innovations and the impact factors in service sector in Liepaja City, observing the dominating role of the field of services in economics. The traditional field of economics in Liepaja City is not only the production but also different service fields, such as transportation and storage, sale and car repairs. In accordance with Liepaja City Development Program 2015-2020 (Liepājas pilsētas Dome, 2015), these fields have an important role in terms of economic indicators and provision of jobs. Their development depends on the improvement of productivity, which is influenced by the ability to attract highly qualified employees and introduce innovative solutions.

Authors not only have studied the trends of the introduced innovations, but they wanted also to identify the factors delaying the introduction of innovations specifically in the service companies in Liepaja. There is no public statistical data showing the level of innovations in Liepaja companies, but the common trend in Latvia shows that the number of innovative service companies is decreasing. According to the data from Innovative activity report 2016 of 
Daina VASIḶEVSKA, Diāna LİDUMA, Kitija MELBERGA. Factors affecting innovations in service sector enterprises: The case of Liepaja

PROBLEMS

OF MANAGEMENT IN THE $21^{\text {st }}$ CENTURY Vol. 12, No. 1, 2017

Central Statistics Bureau (hereinafter - CSP) of the Republic of Latvia, the innovative service companies make $23.4 \%$ of all companies in the last reporting period 2012-2014 (CSP, Inovācijas, 2016). That proportion has reduced by $8 \%$, when comparing with the previous reporting period (2010-2012). In addition, the common indicators of Latvian innovative business activity are low. According to EIS 2016 information, Latvia takes the $25^{\text {th }}$ place from 28 EU Member States (by indicators of 2015). The neighboring country Lithuania takes the $24^{\text {th }}$ place, but Estonia - the comparatively high $14^{\text {th }}$ place (European Innovation Scoreboard, 2016). When comparing the total performance of the Baltic States to each other, the performance of Latvia is the lowest only in 2015. It managed to get out of the modest innovators group (results considerably below the average ES indicators) and get into the moderate innovators group (results below the average EU indicators) where currently all three Baltic States are included. (European Innovation Scoreboard, 2016) In accordance with Innobarometer report 2016, 61\% of companies in Latvia have introduced at least one innovation since January 2013 and it comes close to the average indicators of EU Member States that is 67\%. (Innobarometer $2016-\mathrm{EU}$ business innovation trends, 2016). Latvian researchers A. Deniņš and F. Lipmans point out that Latvian companies use non-systemic approach in the innovations management. That means that innovations in companies are introduced only periodically and there is no tangible influence of those innovations on the growth and development of a company. In general, it does not increase the competitiveness of the company. (Deninš, Lipmans, 2012) According to Innobarometer 2016 data, companies in Latvia encounter different factors preventing the introduction of innovations (Innobarometer 2016 - EU business innovation trends, 2016). Authors suggest, it updates the existing business problems in general, including also the innovative activity of the service sector.

The experience of other scientists was reviewed regarding the forms of innovations specifically in the companies in service sector. The conclusion of the researcher's Morrar report about the signs characteristic to innovations in the manufacturing and service sectors of France (2014) must be noted. He states that the most popular innovations in the service sector are the organizational innovations that are followed by marketing and process innovations and finally - the product innovations. In addition, it is established that the service sector makes larger investments in the innovation by implementing different training events and information and communication technologies. (Morrar, 2014) Researchers Engen and Holen, referring to Sun$d b o$ and Gallouj have stated that innovations linked to the service processes and development of ideas usually are characterized as the supplementing ones. They explain that the supplementing innovations in the field of services are usually small improvements to the existing services or to the service provision process. But radical innovations mean changes that have important influence on the market by changing the market structure or creating a new market. (Engen, Holen, 2014) The researchers Mina, Bascavusoglu-Moreaul and Hughes have emphasized that open innovations are observed more frequently in the services than in the manufacturing. (Mina, Bascavusoglu-Moreau1, Hughes, 2014) As the Latvian researchers E. Zelgalvis and others have stated, open innovations successfully combine the internal and external ideas and market channels to facilitate the development of new technologies. (Innovations and Latvian economy: monography, 2011)

In Latvia there is a trend to emphasize specifically the technological side of the innovations. Referring to the explanation of ideas given in the "National industrial policy guidelines 2014-2020", innovations are divided in two groups: non-technological innovations, which include the organization and marketing innovations, and technological innovations, which include the product and process innovations. (National industrial policy guidelines 2014-2020, 2013) However, in the Oslo handbook, which is the guideline for innovation data collection and interpreting and is elaborated by Organization for Economic Cooperation and Development (hereinafter - OECD), classification by innovation object is used by dividing the following forms of innovations: product innovations, process innovations, marketing innovations and organizational innovations. (OECD, 2005) This is one of the most popular classification 
of innovations that is used in practice in different innovations inquiries in the business sector. The authors of the article have chosen to apply it when studying the forms of innovations in the sector of companies in Liepaja and when determining the impact factors in introduction of innovations.

Several scientific researchers in Latvia, Poland, Spain, Portugal, France, Norway, Nigeria and elsewhere in the world state that innovations in the service sector are less influenced by impedimental factors, thus creating a high potential of innovation in service companies. Researches made in different EU states show similar results - service sector is more sensitive to internal impact factors. Factors such as the lack of human resources and finances are mentioned. For example, in Morrar's research the lack of resources, innovation costs, and indefinite demand for the end-results of innovation are mentioned as the main obstacles in the service sector in France. (Morrar, 2014) Similar factors are identified in the tourism companies in the southern part of Poland. In the research it is noted that the lack of financial capital is just as common as other obstacles related with the staff determination, innovation protection and technical support. It is confirmed that the main preventing factor in tourism companies in Poland is human resources, especially insufficient skills, competences and low qualifications, as well as low motivation to get involved in the innovation processes. (Najda-Janoszka, Kopera, 2014) The results obtained by Silva together with other researchers who studied the innovation activities in the service companies in Portugal showed that the financial investments in different innovation activities give positive and important effect for the innovations in services. (Silva, Sousa, et al., 2011) The researchers A. Deninš and F. Lipmans in 2012 have updated the following as the largest obstacles for innovations in the companies in Latvia: 1) the companies implement short-term planning, focusing on quick achievements and instant profit and no strategic company development plans or visions are developed; 2) the companies involve lazily in the innovative activity, there is insufficient cooperation between the businessmen and scientists in development of innovations; 3) low state funding for the science and research; 4) due to the organizational structure the innovation process is chaotic in large and medium companies and it is not managed deliberatively; however innovation management is needed to get profit and increase the added value of the company, thus facilitating the competitiveness of the company; 5 ) in Latvia there is no legislation beneficial and facilitating enough and governmental support which would motivate a company to develop the innovative activity. (Deninšs, Lipmans, 2012) However, when researching the innovation in the Baltic States, I. Dubra in 2014 has concluded that the innovative companies in Latvia and Lithuania introduce innovations more frequently if they have better access to the human resources. A friendly internal environment and possibilities of open cooperation in the innovative companies of Latvia help to introduce the product innovations more easily. However, the same factors help to introduce successfully all forms of innovations in the innovative companies in Lithuania (Dubra, 2014). Referring to the opinion of the researchers Sundbo and Gallouj, the researchers Engen and Holen note that innovations in service companies are advanced mainly by the internal factors: company's management and strategy; employees at all levels; and R\&D departments. In addition, the first two factors are the main ones. (Engen, Holen, 2014) According to the Innobarometer research, the most frequently named preventing factor in the Baltic States and in EU Member States is the dominating experienced competitors. In Latvia, this factor is named by $82 \%$ of the inquired companies, but the second place in the Baltic States is taken by the lack of financial resources, the third place - lack of human resources. However, the difficulties to protect the intellectual property rights is mentioned least as a preventing factor for innovations in the Baltic States. This is true also in EU Member States. (Innobarometer 2016 - EU business innovation trends, 2016)

The sector of Liepaja service companies was chosen because the importance of this sector in the growth of the city as mentioned in the city development program to 2020 . The managers of the service companies have to make important decisions related to the growth of business. Lack of information characterizing the current situation about the innovative business in Liepaja City may be an obstacle for management of innovations when making decisions and planning solutions to promote the innovative activity. 
Daina VASIḶEVSKA, Diāna LİDUMA, Kitija MELBERGA. Factors affecting innovations in service sector enterprises: The case of Liepaja

\author{
PROBLEMS \\ OF MANAGEMENT \\ IN THE $21^{\text {st }}$ CENTURY \\ Vol. 12, No. 1, 2017 \\ 72 \\ The aim of the research is to clarify the opinions of managers of service companies in \\ Liepaja about the most current forms of innovations and factors influencing innovations.
}

\title{
Methodology of Research
}

\section{General Background of Research}

Although initially the importance of innovation in business was related with the manufacturing sector, different researchers (Morrar, Najda-Janoszka, Kopera, Silva, and others) have addressed their researches in the field of services as well for more than 20 years.

In general, it is to be concluded that the most often studied factors influencing innovations are: the size of a company, market structure, human resources, financial resources and $\mathrm{R} \& \mathrm{D}$ activities. Methodological innovations are mainly emphasized in the service sector, which are supplements to a service, related with development of ideas and organizational structures. Within the framework of the research, the authors want to receive answers to the questions: what form of innovations are introduced most frequently by the service companies in Liepaja and what factors influence the introduction of innovation in the service companies in Liepaja?

Managers of service companies in Liepaja were inquired within the framework of the research to obtain data about the innovation of service companies in Liepaja and the impacting factors in the introduction of innovations.

The inquiry took place from October 22 to November 8, 2016. The questionnaire was placed on the website www.visidati.lv and the authors of the research sent the link to the questionnaire to e-mail addresses of respondents.

The link to questionnaire was sent in total to 154 companies in Liepaja. In the result answers from 31 respondents were received, i.e. $20 \%$ from all addressed respondents. $90 \%(n=31)$ of respondents in the questionnaire were the highest-level managers, directors, members of the board or CEO. $26 \%$ of respondents represented municipal companies, $74 \%$ - private companies. All respondents represented a limited liability company. Joint-stock companies, individual merchants or companies of other forms of business were not represented in the questionnaire. When comparing the companies by age, almost half or $48 \%(n=31)$ of the inquired companies are at the age of $10-19$ years, the age of $32 \%$ companies is $5-9$ years, $13 \%-20$ and more years, and the smallest group - $6 \%$ are companies younger than 5 years. $45 \%$ of all respondents were companies with 1-9 employees, $48 \%$ - with 10-49 employees and 7\% - with 50-250 employees, but companies with 250 or more employees did not participate in the questionnaire. Thus, micro or tiny companies have participated in the questionnaire. It is to be concluded that the municipal companies were more responsive than the private ones, because $73 \%$ of all invited municipal companies completed the questionnaire, but the responsiveness from the private companies was $16 \%$, and the obtained data attest the trends that are expressed principally by experienced and long-time managers of companies.

\section{Sample of Research}

In accordance with the data summarized by Lursoft, there were 2531 active service companies in Liepaja in 2015, which makes $74 \%$ of all companies (including not only the subjects of the commercial register, individual merchants and commercial companies, but also the selfemployed persons, farmers and fishers farms). (Lursoft, List of active enterprises..., 2016) The required selection was formed as the non-probable selection. The initial selection method - typical occasion, but then the convenience method was used, thus initially selecting part of the service companies in Liepaja, from which companies were chosen whose e-mail addresses were available for the authors of the research. In the research authors included economically active companies which have submitted the annual accounts 2015 (except if the company was registered in 2016) that are the subject of the commercial register - individual merchants and commercial companies. 
Considering that a narrow group of service companies is included in the CSP surveys $\mid \begin{aligned} & \text { PROBLEMS } \\ & \text { OF MANAGEMENT } \\ & \text { IN THE 21 } \text { It }^{\text {st }} \text { CENTURY } \\ & \text { Vol. 12, No. 1, } 2017 \\ & 73\end{aligned}$ about the innovations, service companies in Liepaja were included in the selection of the research inquiry according to the grouping used in the CSP Service companies turnover index (CSP, Pakalpojumu uzñēmumu..., 2016). Included were companies whose principal place of activity is Liepaja and legal address is registered also in Liepaja. The authors of the research have not included all fields of the service sector in the selection, because such fields as retail, education and healthcare are fields that must be researched individually due to their different peculiarities of the activity.

\section{Instrument and Procedures}

Within the framework of the research, a questionnaire with 25 questions (incl., 5 demographic questions of companies) by means of which the principal information about a company and the main indicators of activity, information about the former and planned innovations, and factors impacting the innovations and growth of a company were clarified. Structure of the questions is formed mainly by closed questions. The selected origin of time in the questionnaire is from January 2014, which conforms to the introduction of euro in Latvia. Such point of reference is chosen so that for the respondents it is easier to determine for what time period information is needed when answering the questions. According to OECD, the suggested reporting period in the innovations surveys is from one to three years (OECD, 2005), thus the period selected in the research falls within the specified limits.

\section{Data Analysis}

Statistical data processing methods were used: descriptive statistics, contingency method. Microsoft Excel application software was used to process the quantitative data of research. The obtained data are displayed in tables and graphs by means of diagrams.

\section{Results of Research}

In the research, it was clarified that $90 \%(\mathrm{n}=31)$ of questioned service companies in Liepaja have introduced at least one form of innovations since January 2014. In the research it was established that mainly product (a new or materially improved service) $(74 \%)$ or process innovations (74\%) were introduced by object in the service companies (Figure 1).

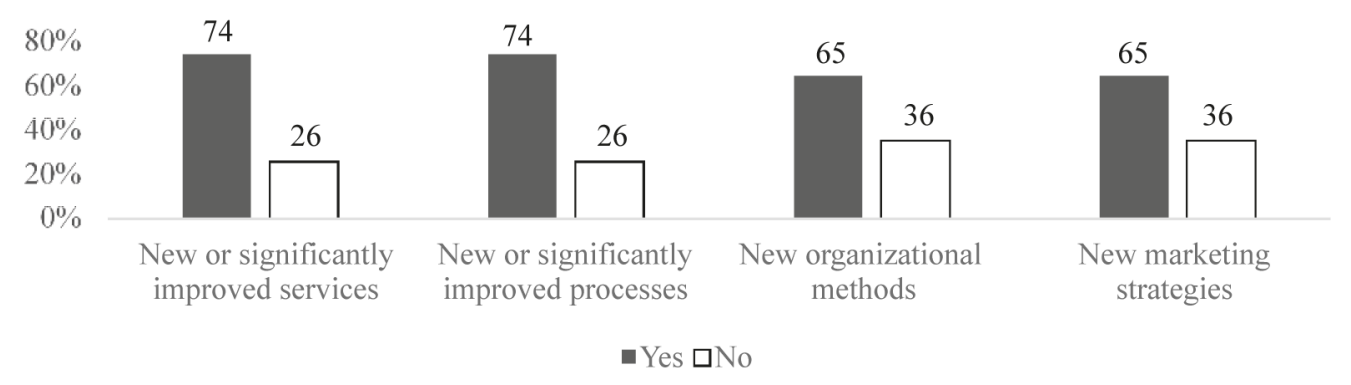

\section{Figure 1: Forms of innovation introduced in the service companies in Liepaja $(n=31), \%$.}

The results of the research show that $42 \%$ of the questioned companies have introduced innovations of all four forms. $23 \%$ have introduced three forms, $16 \%$ - two forms, $10 \%$ - one form of innovations within the specified period, but the remaining $10 \%$ of companies have not introduced any innovation (they are 10 years old or older companies that all represent the area 
Daina VASIḶEVSKA, Diāna LĪDUMA, Kitija MELBERGA. Factors affecting innovations in service sector enterprises: The case of Liepaja

PROBLEMS

OF MANAGEMENT IN THE $21^{\text {st }}$ CENTURY Vol. 12, No. 1, 2017

of transportation and storage). If $42 \%$ of the questioned companies have introduced all forms of innovations, then $6 \%$ are such companies that not only have introduced all forms of innovations, but also plan to introduce all forms of innovations within the next 12 months. However, only $35 \%(n=31)$ of the companies could clearly answer about their plans as to the introduction of innovations in future. Forms of innovations planned by the companies within the next 12 months can be seen in Figure 2.

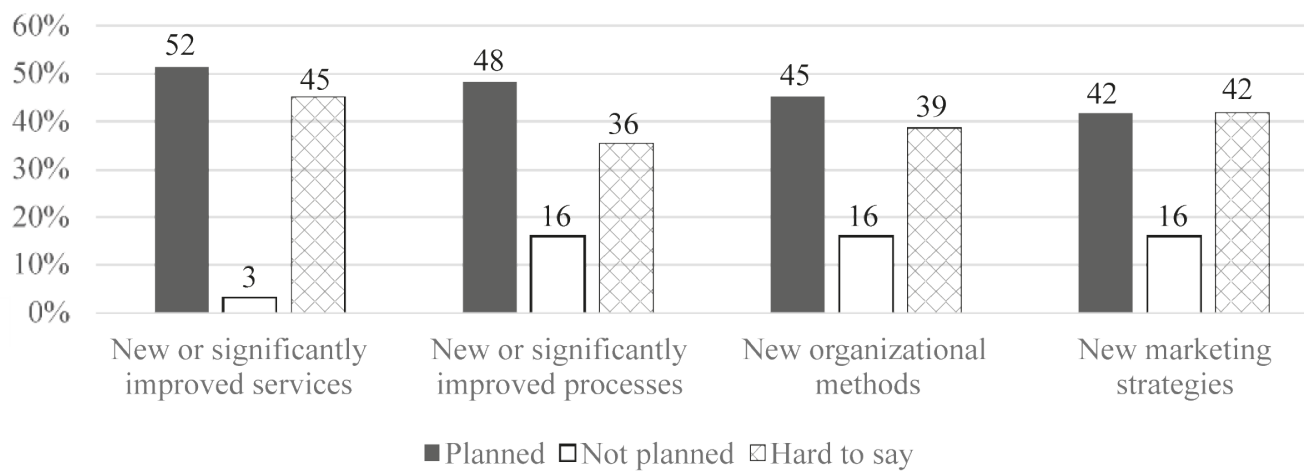

\section{Figure 2: Innovations planned by the service companies in Liepaja within the next 12 months $(n=31) \%$.}

$39 \%(n=31)$ of managers of the questioned companies believe that among the different internal and external factors impacting the service sector (geographic location, demand, situation in the area, overall economic situation, tax policy, normative regulation, attraction of external funding, employees of the company, etc.), introduction of innovations facilitates the total business growth of the specific company (Figure 3).

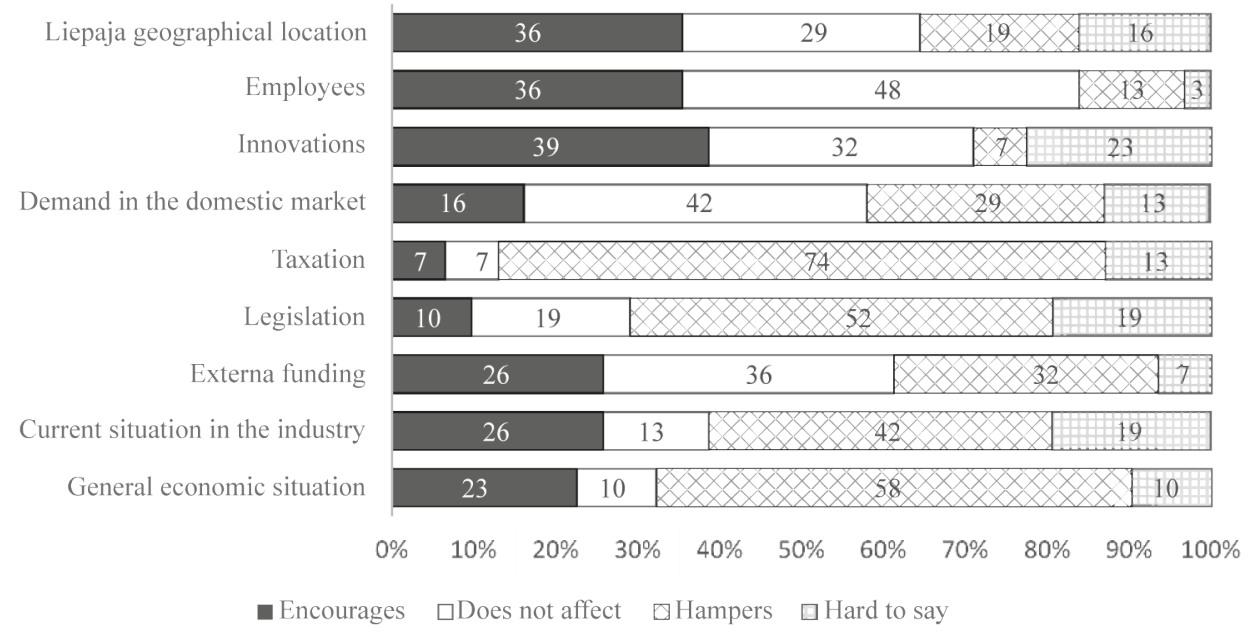

Figure 3: Business growth incentives and disincentives in service companies in
Liepaja $(n=31), \%$.

The results attest the opinion of $32 \%(n=31)$ respondents that introduction of innovations does not influence the growth of a company. $7 \%(n=31)$ have noted that it even prevents the growth of a company (in these companies at least three forms of innovations were introduced since January 2014 and the companies plan to introduce innovations also further or couldn't 
Daina VASIḶEVSKA, Diāna LİDUMA, Kitija MELBERGA. Factors affecting innovations in service sector enterprises: The case of Liepaja

give a clear answer yet). For another $23 \%$ of respondents it was difficult to give a specific opinion (all these companies were private service providers, $14 \%$ of which have not introduced

PROBLEMS OF MANAGEMENT IN THE $21^{\text {st }}$ CENTURY Vol. 12, No. 1, 2017 any innovations, but $86 \%$ of which have introduced 2-4 forms of innovations). All managers of the companies $(39 \%)(n=31)$, who see that innovations facilitate the growth of business, have introduced and plan to further introduce some innovations.

The main factors preventing the innovation in a service company are identified in the research - the preventing factor that was stated most frequently was the lack of financial resources $(52 \%)(n=31)$, the new service sale risk was in the second place $(42 \%)$, in the third place - lack of demand which was noted by $35 \%$ of the companies (Figure 4 ).

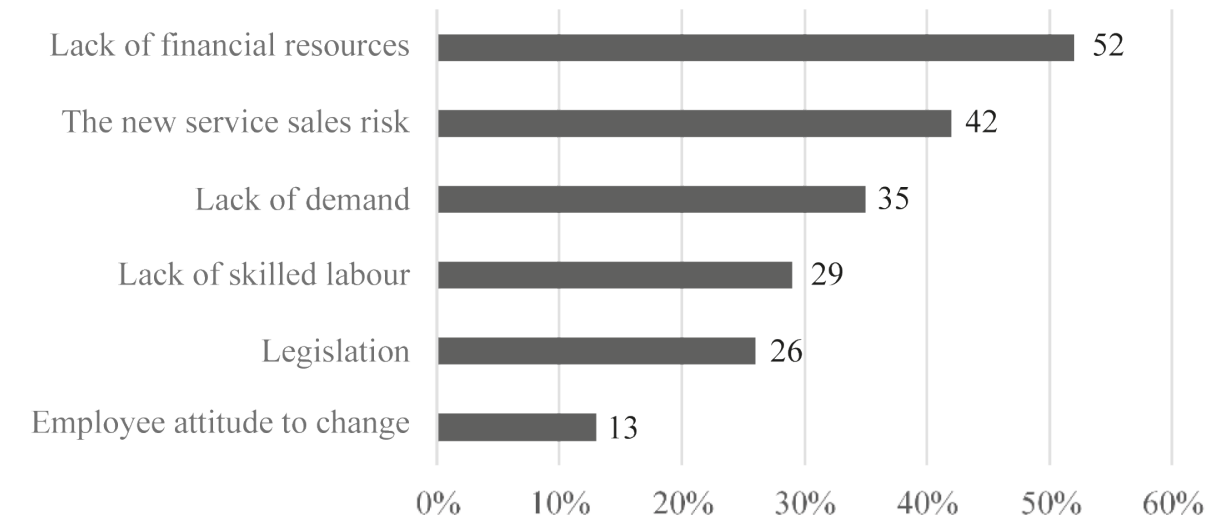

\section{Figure 4: The preventing factors stated more frequently in the service companies in Liepaja $(n=31)$,.}

Having assessed the impact of the previously named factors in the implementation of innovative activity, it was concluded that $13 \%(n=31)$ of the managers of companies note specifically the lack of qualified employees as an "insurmountable problem" to innovative activity of service companies. In 3\% of cases the lack of financial resources remains as an "insurmountable problem". It was already noted previously in the common results that in $45 \%(n=31)$ of companies it is noted as a "significant obstacle" and $61 \%(n=31)$ of respondents have noted the service sales risk as a "significant obstacle" (Figure 5).

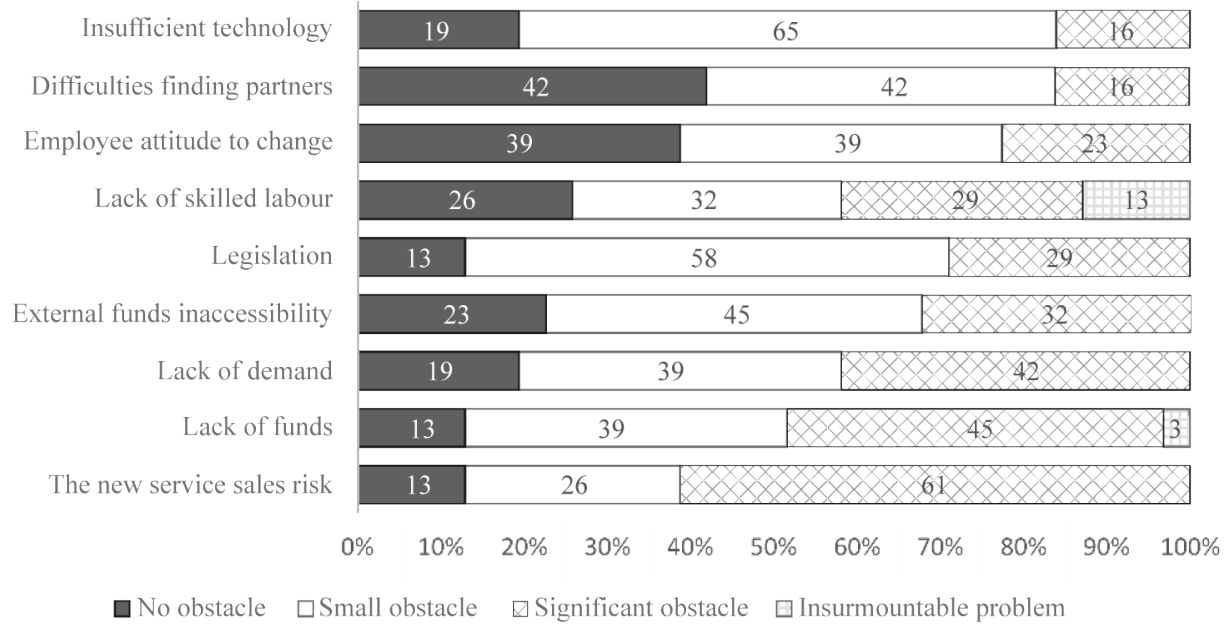

Figure 5: Factors affecting innovations in service companies $(n=31), \%$. 
Daina VASIḶEVSKA, Diāna LĪDUMA, Kitija MELBERGA. Factors affecting innovations in service sector enterprises: The case of Liepaja

PROBLEMS

OF MANAGEMENT IN THE $21^{\text {st }}$ CENTURY Vol. 12, No. 1, 2017

When answering the additional question: "Whether the company has received any financial support for innovative activities since 2014?", $68 \%$ (n=31) of the questioned service companies stated that they have not received any financial support. $10 \%$ of these companies are informed about the available support measures for the innovative activity of companies in Latvia, $52 \%$ are partially informed, but $38 \%$ are not informed. The obtained data shows the trend of lack of information for the support of innovative activities in the service companies.

In the research, it was established that the main factors facilitating the innovation in service companies are: competitiveness (noted by more than half or $61 \%(n=31)$ of the questioned respondents); market potential - $42 \%$ of respondents and the same number of companies have noted the available information and communication technologies (Figure 6).

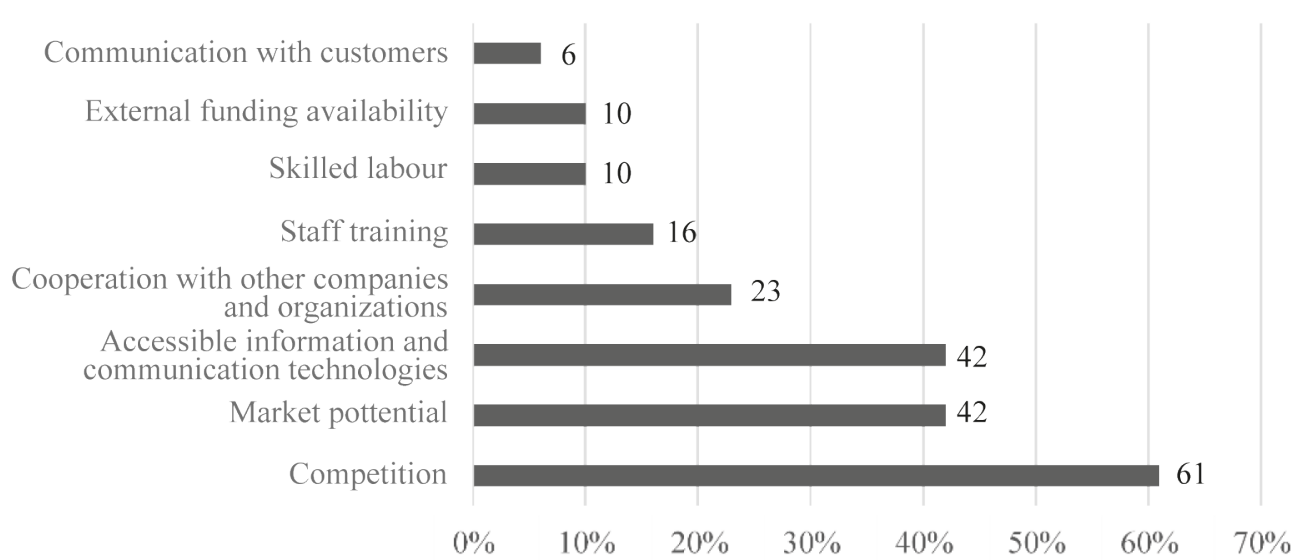

\section{Figure 6: The facilitating factors stated more frequently in the service companies in Liepaja $(n=31), \%$.}

In the research, data are obtained about the changes in the indicators of activity of individual service companies (number of employees, turnover, and profit) that have occurred since January 2014 (Figure 7).

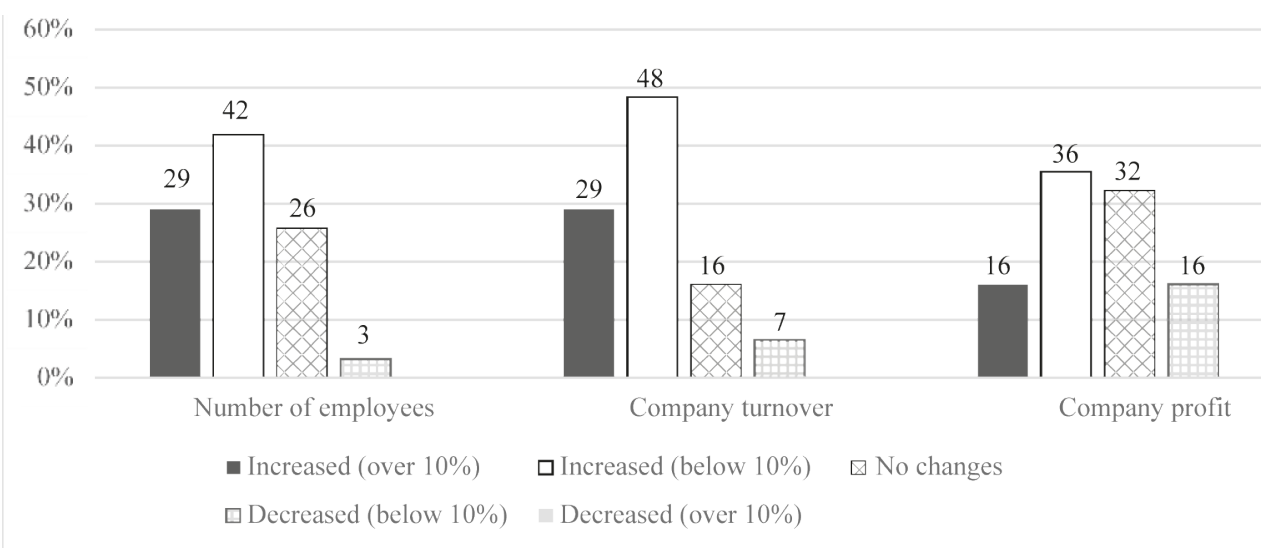
Figure 7: changes in the growth indicators of the questioned companies since
January $2014(n=30), \%$

The results show that all $71 \%$ of the questioned service companies that have noted the increase of number of employees to or above $10 \%$, have introduced at least one form of innova- 
tions within the relevant period. $96 \%$ of the $77 \%$ of companies that have noted the increase of Vol. 12, No. 1, 2017

turnover to or above $10 \%$, have introduced at least one form of innovations, but $94 \%$ of $52 \%$ of companies that have noted the increase of profit to or above $10 \%$, have introduced at least one form of innovations since January 2014.

The results of the research show that the companies that have noted the increase of the number of employees, have introduced the product and process innovations $(61 \%$ and $61 \%)$, i.e. technological innovations more frequently than the organizational and marketing innovations (respectively, $48 \%$ and $48 \%$ ). In addition, the companies that have noted the increase in any of the financial indicators, have also more frequently introduced the technological innovations; however, the prevalence over the introduced non-technological innovations $(55 \%$ and $58 \%$ ) is quite small (Table 1 ).

Table 1. Growth indicators and innovations in service companies, \%.

\begin{tabular}{llllll}
\hline Introduced innovation & $\begin{array}{l}\text { Increase in at } \\
\text { least one of the } \\
\text { indicators }\end{array}$ & $\begin{array}{l}\text { Increased turno- } \\
\text { ver or profit }\end{array}$ & $\begin{array}{l}\text { Increased } \\
\text { number of } \\
\text { employees }\end{array}$ & $\begin{array}{l}\text { Increase in all } \\
\text { indicators }\end{array}$ & $\begin{array}{l}\text { Increase in } \\
\text { all indicators } \\
\text { over 10\% }\end{array}$ \\
\hline Product innovations & 68 & 61 & 61 & 35 & 10 \\
\hline Process innovations & 68 & 61 & 61 & 42 & 13 \\
\hline $\begin{array}{l}\text { Organizational innova- } \\
\text { tions }\end{array}$ & 61 & 55 & 48 & 29 & 10 \\
\hline Marketing innovations & 58 & 58 & 48 & 29 & 10 \\
\hline
\end{tabular}

When assessing the statements of respondents about the relation of changes in company's indicators (number of employees, turnover, profit, costs) with the innovative activity of the company, it was established: $36 \%$ of the companies that have noted the increase of number of employees (to or above 10\%) and have introduced at least one innovation, have stated that they completely agree or disagree that it has happened due to the innovative activity; $52 \%$ of the companies that have noted the increase of turnover (to or above 10\%) and have introduced at least one innovation, have stated that they completely agree or disagree that it has happened due to the innovative activity, and $60 \%$ of the companies that have noted the increase of profit to or above $10 \%$ and have introduced at least one innovation, have stated that they completely agree or disagree that it has happened due to the innovative activity.

\section{Discussion}

The practice of service companies in Liepaja to introduce the technological innovations in the service sector contradicts the common situation in Latvia - according to CSB data, more than half of the innovative companies in the service sector in Latvia implement specifically the non-technological innovations (CSB, Innovations, 2016). The trend of service companies in Liepaja to introduce the product and process innovations differs also from the practice of service companies in other countries, e.g. France, where the organizational innovations are the most popular ones, that are followed by marketing and process innovations, and finally - by product innovations. As it is stated by Morrar, the economic impact of a technological innovation is the largest, when comparing with other forms of innovations. Usually they are the main innovation activities in the manufacturing sector and proving that the technological innovations in the service sector are more efficient if supplemented by non-technological innovations (new organizational approaches, standardized methods of management control, marketing designs and procedures) (Morrar, 2014). The service companies in Liepaja should take into account this fact when planning their further innovations. In the future the introduction of forms of 
Daina VASIḶEVSKA, Diāna LİDUMA, Kitija MELBERGA. Factors affecting innovations in service sector enterprises: The case of Liepaja

PROBLEMS

OF MANAGEMENT

IN THE $21^{\text {st }}$ CENTURY Vol. 12 , No. 1, 2017

78

technological innovations in service companies in Liepaja should be planned together with the implementation of non-technological innovations, thus strengthening the contribution of the technological innovations in the growth of the business.

The short-term planning factor in the innovations management (lack of strategies and innovation aims) in service companies in Liepaja revealed in the research (for $65 \%$ of companies it was "difficult to say" about the planned forms of innovations within the next 12 months), corresponds with the previously identified obstacles of innovative activity in Latvia. Already in 2012, Deninš and Lipmans, having researched the innovations in Latvia, made a conclusion that short-term planning is implemented in the companies. (Deniņš, Lipmans, 2012) It testifies that the approach of management to innovative activity of the companies has not changed during five years. Managers of service companies have not effected any changes to eliminate this internal factor.

The lack of financial resources is topical in the innovations management in service companies in Liepaja and it is noted as the main preventing factor. In the researches previously made in Latvia it was stated only as the third preventing factor (Deniņš, Lipmans, 2012), but in Innobarometer 2016 it is fixed as the second preventing factor in the companies in the Baltic States in general. (Innobarometer 2016 - EU business innovation trends, 2016) As the results of different researches show, this factor is noted also in service companies in other European countries. The authors draw a conclusion that specific support measures are needed for the service companies in Liepaja regarding the issue with financial resources. However, more active informing about the existing possibilities must be provided (only $7 \%$ of the companies that have noted the lack of financial resources as an "significant obstacle" or "insurmountable problem" were informed about the available support measures for innovative activity, $60 \%$ were informed partially, but $33 \%$ are not informed at all).

Managers of companies in Liepaja note the lack of qualified workforce as an "insurmountable problem" in the innovation management of service companies. The results obtained in Liepaja City contradict the data of EIS 2016 where the human resources, company investments, and financial and support dimension had the highest results in the innovation ability dimensions in Latvia, where they are equal or close to the EU average indicators. (European Innovation Scoreboard, 2016) It should be noted that employees as one of the main factors in the innovation process is outlined in several researches in different countries. Similar conclusions are drawn also by Engen and Holen in their research about the service companies in Norway (Engen, Holen, 2014) and it is fixed also by Najda-Janoszka and Kopera as an existing problem in the tourism service companies in Poland. (Najda-Janoszka, Kopera, (2014) It should be taken into account that innovative business is directly based on knowledge and the management of service companies must plan the solution to obtain and provide them in their companies.

All respondents who regard that innovations facilitate the growth of a company (39\%) have implemented at least one form of innovation in their company. Considering that $23 \%$ of respondents have noted that it is difficult to say whether the introduction of innovations impacts the growth of the particular company and all these companies were private, not municipal service providers, $14 \%$ from which haven't introduced any innovations, but $86 \%$ of which have introduced 2-4 forms of innovations, it is concluded in the research that in the companies in the private sector there is a trend not to analyze the results of introducing innovations and their impact on other processes in the company.

According to the information provided by the respondents, having assessed the changes in company's indicators (number of employees, turnover, profit) that have happened since January 2014, an increase above or to $10 \%$ in the number of employees, turnover and profit indicators were established in $42 \%$ of the questioned companies. All these companies have introduced at least one form of innovations since January 2014. 93\% of the questioned companies who have introduced at least one form of innovations have observed an increase in at least one of the company's indicators - increase of the number of employees, turnover or profit. $82 \%$ of the questioned companies who have introduced at least one form of innovations, have observed 
an increase in any of the company's indicators, but $79 \%$ of the questioned companies who

have introduced at least one form of innovations, have observed the increase in the number of employees. A trend is outlined that the introduced innovations in the service companies in Liepaja improve the growth indicators of these companies, not excluding also the impact of other factors. The managers of the questioned companies give partial approval of this thesis too. A trend is outlined that managers of service companies in Liepaja link the positive changes in the financial indicators more frequently with the introduction of innovations in the companies, and all managers of the companies who see that innovations facilitate the growth of business, have introduced and plan to further introduce innovations.

\section{Conclusions}

In general, the results of the research show that each of the researched service sector companies in Liepaja has introduced an innovation during the last three years. Service companies in Liepaja introduce the product and process innovations. The number of companies that have introduced the organizational or marketing innovations is a bit smaller. In the research, it was established that those service companies in Liepaja who have introduced product innovations, introduce process innovations most frequently as well, and vice versa. $16 \%$ of all questioned service companies not only have introduced all forms of innovations (product, process, organizational and marketing), but also plan to introduce all the mentioned innovations during the next 12 months. However, for $65 \%$ of the companies it was "difficult to say", when answering about any of the planned forms of innovations during the next 12 months. These results show the lack of strategy, innovation aims and short-term planning in the service companies in Liepaja.

Despite the fact that the lack of financial resources outlines as the primary factor preventing innovations in the service sector in Liepaja, managers of service companies in Liepaja consider the lack of qualified employees specifically as an "insurmountable problem" in successful implementation of innovations (13\%), but the new products sales risk as a "significant obstacle" (61\%).

It was established that the main factors facilitating the innovations in the service companies in Liepaja is the competitiveness, market potential, available information and communication technologies. Competitiveness and the market potential are external factors and the company cannot influence them directly. Whereas the purchase or improvement of the information and communication technologies, cooperation with other companies, training of employees are internal factors that can be implemented by the company to improve the innovative activity of a service company.

Concluded that $93 \%$ of the companies that have introduced at least one form of innovations have observed an increase in at least one of the company's indicators, increase of the number of employees, turnover or profit. For the managers of the service companies it is usually difficult to assess and give their opinion about the impact of innovations on the growth of the company. The impact of innovations is not analyzed separately in the companies so the respondents are not able to assess it.

The results attest the trend that the companies link the positive changes in the financial indicators more frequently with the introduction of innovations in the companies, but the increase of the number of employees - not so often. That can be explained with the fact that the number of employees may also reduce as the result of a successful innovation.

A slight prevalence of technological innovations over the non-technological ones is observed in the companies that have observed positive changes in the number of employees and in the companies that see positive changes in the financial indicators in the results of innovations. 
Daina VASIḶEVSKA, Diāna LİDUMA, Kitija MELBERGA. Factors affecting innovations in service sector enterprises: The case of Liepaja

\author{
PROBLEMS \\ OF MANAGEMENT \\ IN THE $21^{\text {st }}$ CENTURY \\ Vol. 12, No. 1, 2017 \\ 80 References
}

CSP (2016). Inovācijas. [Innovations]. Retvieved from: http://www.csb.gov.lv/statistikas-temas/inovacijas-galvenie-raditaji-30336.html

CSP (2016). Pakalpojumu uznе̄emumu apgrozījuma indekss. [Service companies turnover index]. Retvieved from: http://www.csb.gov.lv/statistikas-temas/metodologija/pakalpojumu-uznemumuapgrozijuma-indekss-37468.html

Deninšs, A., Lipmans, F. (2012). Inovāciju vadība Latvijas uzn̦ēmumos un to ietekme uz uzn̄ēmumu konkurêtspēju. [Innovation management in Latvian enterprises and their impact on the competitiveness of businesses]. Latvijas Universitātes raksti 2011 Ekonomika. Vadības zinātne, 771. sējums, 442.-456. lpp. Retvieved from: http://www.lu.lv/fileadmin/user_upload/lu_portal/apgads/PDF/LUR-771_Vad-zin_353-672lpp_.pdf

Dubra, I. (2014). Inovācijas Baltijas valstīs un to ietekmējošie faktori: Promocijas darbs. [Innovations in the Baltic States and its influencing factors: a doctoral thesis.].. LU Ekonomikas un vadības fakultāte. Rīga: Latvijas Universitāte, $225 \mathrm{lp}$. Retvieved from: https://dspace.lu.lv/dspace/bitstream/handle/7/5239/41932-Ilona_Dubra_2014.pdf?sequence $=1$

Engen, M., Holen, I. E. (2014). Radical Versus Incremental Innovation: The Importance of Key Competences in Service Firms. Technology Innovation Management Review, 4(4), p. 15-25. Retvieved from: http://timreview.ca/article/781

European Innovation Scoreboard 2016. (2016). European Commision. Retvieved from: http://ec.europa. eu/growth/industry/innovation/facts-figures/scoreboards_en

Innobarometer 2016 - EU business innovation trends. (2016). European Commision. Retvieved from: https://ec.europa.eu/growth/industry/innovation/facts-figures/innobarometer_en

Inovācijas un Latvijas tautsaimniecība: monogräfija. (2011). [Innovations and Latvian economy: monography]. E. Zelgalvis u.c. Rīga: LU Akadēmiskais apgāds. 167 lpp.

Liepājas pilsētas Dome. (2015). Liepājas pilsētas attīstības programma 2015.-2020.gadam. [Liepaja City Development Program 2015-2020]. Retvieved from: http://www.liepaja.lv/upload/attistibas_strategija/strategiska_dala_23_01_2015.pdf

Lursoft. (2016). Aktīvo uzn̄èmumu skaits, sakārtots pēc nozares 2015. gad̄̄. [Number of active companies, sorted by industry in 2015]. Retvieved from: https://www.lursoft.lv/lursoft_statistika/?\&no vads $=100003044 \& i d=516$

Mina, A., Bascavusoglu-Moreau1, E., Hughes, A. (2014). Open service innovation and the firm's search for external knowledge. Research Policy, (Volume 43, Issue 5, p. 853-866). Retvieved from: http://www.sciencedirect.com/science/article/pii/S0048733313001200

Morrar, R. (2014). Innovation in French services compared to manufacturing: an empirical analysis based on CIS4. Journal of Innovation Economics \& Management, 2014/1, n¹3, p. 175-203. Retvieved from: https://www.cairn.info/revue-journal-of-innovation-economics-2014-1-page-175. $\mathrm{htm}$

Nacionālās industriālās politikas pamatnostādnes 2014.-2020.gadam. (2013). [National industrial policy guidelines 2014-2020]. Retvieved from: http://polsis.mk.gov.lv/documents/4391

Najda-Janoszka, M., Kopera, S. (2014). Exploring barriers to innovation in tourism industry - the case of southern region of Poland. Procedia - Social and Behavioral Sciences, 110, 190 - 201. Retvieved from: http://www.sciencedirect.com/science/article/pii/S187704281305502X

OECD. (2005). OSLO rokasgrāmata: Pamatnostādnes inovācijas datu vākšanai un interpretācijai [OSLO Manual: Guidelines for innovation in data collection and interpretation ]. (3. izd.). Retvieved from:

http://www.vvc.gov.lv/advantagecms/LV/tulkojumi/dokumenti.html;jsessionid=C64994EBEB7D610A8 33CDABBAA036B40?folder=\%2Fdocs\%2FSTA\%2FTulkojumi_no_anglju_val\%2FRokasgram atas $\% 2$ F\&currentPage $=2$

Silva, M. J., Sousa, G., Moreira, J., Simoes, J. (2011). Innovation Activities in the Service Sector: Empirical Evidence from Portuguese Firms. Journal of Knowledge Management, Economics and Information Technology, October 2011, Issue 6. Retvieved from: http://www.scientificpapers.org/ wp-content/files/1182_Maria_Jose_Silva_INNOVATION_ACTIVITIES_IN_THE_SERVICE_ SECTOR_EMPIRICAL_EVIDENCE_FROM_PORTUGUESE_FIRMS.pdf 
Daina VASIḶEVSKA, Diāna LİDUMA, Kitija MELBERGA. Factors affecting innovations in service sector enterprises: The case of Liepaja

Received: May 30, 2017

Accepted: June 26, 2017

PROBLEMS
OF MANAGEMENT
IN THE 21 $1^{\text {st }}$ CENTURY
Vol. 12, No. 1, 2017

$\begin{array}{ll}\text { Daina Vasilgevska } & \text { Dr.sc.administr., Associate Professor, Liepaja University, Liela iela 14, Liepaja, } \\ & \text { LV-3401, Latvia. } \\ & \text { E-mail: daina.vasilevska@gmail.com }\end{array}$

Diāna Lìduma $\quad$ Mg.oec., Lecturer, Liepaja University, Liela iela 14, Liepaja, LV-3401 Latvia. E-mail: diana_liduma@inbox.Iv

Kitija Melberga

Mg.oec. SIA Liepajās Olimpiskais centrs, Liepaja, LV-3401, Brīīibas iela 39, Latvia.

E-mail: melberga.kitija@gmail.com 